\title{
Cooperatives' performance relative to investor-owned firms: a non-distorted approach for the wine sector
}

Antonio D'Amato and Giuseppe Festa

Department of Economics and Statistics, University of Salerno, Fisciano, Italy

Amandeep Dhir

Department of Management, University of Agder, Kristiansand, Norway, and

Matteo Rossi

Department of Law Economics Management and Quantitative Methods,

University of Sannio, Benevento, Italy and

Wyzsza Szkola Bankowa w Poznaniu, Poznan, Poland

\begin{abstract}
Purpose - This study aims to investigate whether significant performance differences between cooperatives and investor-owned firms (IOFs) may exist.

Design/methodology/approach - Based on data from a sample of Italian wine firms for the period from 2009 to 2018, an adjusted measure of performance called earnings before interests, taxes, depreciations and amortizations gross the raw materials cost was adopted to consider the different objectives of cooperatives relative to those of IOFs.

Findings - Empirical evidence shows that in the context under analysis, cooperatives have performed better than IOFs.

Originality/value - Despite the theoretical literature suggesting that the cooperative form of organizations suffers from many weaknesses, these results highlight that cooperatives operating in the wine sector are at least as economically efficient as other organizations, and more specifically, they perform better than for-profit firms. Consequent implications for theory and practice are discussed.
\end{abstract}

Keywords Cooperatives, Investor-owned firms, Performance indicators, Wine businesses, Wine industry, Italy

Paper type Research paper

\section{Introduction}

Cooperatives, which could be defined as "[. . .] people-centred enterprises owned, controlled and run by and for their members to realize their common economic, social, and cultural needs and aspirations" (International Cooperative Alliance - ICA, www.ica.coop), play a crucial role in the economy at the international scale. Over time, their presence has increased worldwide in both developed and developing countries, and their weight in terms of employees and turnover has reached high levels (World Cooperative Monitor, 2018).

Companies with cooperative forms in the world amount to approximately three million, and altogether, they provide work for approximately 280 million persons $(10 \%$ of the

(C) Antonio D’Amato, Giuseppe Festa, Amandeep Dhir and Matteo Rossi. Published by Emerald Publishing Limited. This article is published under the Creative Commons Attribution (CC BY 4.0) licence. Anyone may reproduce, distribute, translate and create derivative works of this article (for both commercial and non-commercial purposes), subject to full attribution to the original publication and authors. The full terms of this licence may be seen at http://creativecommons.org/licences/by/4.0/ legalcode
Received 17 March 2021

Revised 25 July 2021

20 September 2021

Accepted 5 November 2021

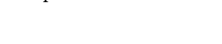


$\mathrm{BFJ}$

124,13

employees in the world); more than $15 \%$ of European citizens are members of a cooperative (Karakas, 2019). More specifically, in Europe, approximately 180,000 cooperatives operate with almost five million employees and a total turnover of approximately one trillion euros, while in the European Union (EU), cooperatives amount to more than 130,000 with almost 4.5 million employees and a turnover of approximately 990 billion euros. Regarding economic activity, $33 \%$ of all cooperatives operate in the agri-food industry and $19 \%$ provide banking and financial services (World Cooperative Monitor, 2018).

Given the pivotal role that cooperatives play in economic development, the institutional and scientific literature has long pointed out their main strengths (Bonus, 1986; Valentinov, 2007). This form of economic organization can better realize scale economies, create new markets or give access to markets in favour of its members; increase market efficiency and reduce transaction costs; manage risk via risk pooling; promote innovation; and so forth.

Compared to investor-owned firms (IOFs), cooperatives are more resilient during economic crises and better able to effectively activate local economies and sustain social inclusion and members' participation (Birchall and Ketilson, 2009). At the same time, a debated line of research in the literature has focussed on the performance of cooperative organizations in comparison to that of IOFs (Grashuis and Su, 2019; Lerman and Parliament, 1990; Soboh at all, 2011), and the results are mixed. While a stream of research shows that cooperatives are inefficient and less profitable than IOFs, other studies suggest that cooperatives are not less efficient and/or profitable than IOFs.

To contribute to this debate, the present study aims to analyse the performance of cooperatives in comparison to that of IOFs to investigate whether and to what extent the cooperative form impacts business performance. To empirically investigate this issue, a focus on the Italian wine industry is deployed.

From a methodological point of view, cooperatives and IOFs differ per their objectives and ownership structures and based on rights granted to owners; in cooperative firms, members/owners are at the same time customers and/or suppliers of raw materials and/or employees. Profit maximization is not their objective, as is the case for IOFs, as they instead pursue the maximization of members' value by offering products and services at affordable prices or, as for cooperatives in the agricultural sector, they can buy raw materials from their members paying higher than market prices (Hart and Moore, 1996).

From these considerations, to avoid generating biased results, in this study, we deviate from the usual literature on cooperative performance, which focusses predominantly on classical measures of financial performance, by adopting an adjusted measure based on earnings before interests, taxes, depreciations and amortizations (EBITDA) gross the cost of raw materials. For a unique data set for a large sample of cooperatives and IOFs operating in the Italian wine industry over the period of 2009-2018, the results show that wine cooperatives have performed better globally than IOFs.

This research contributes to the literature on cooperative performance in several ways: First, we consider the different business goals of cooperatives relative to those of IOFs, allowing the construction of a more accurate measure of performance; second, we develop an empirical analysis focussed on the Italian wine industry, in which cooperatives play a crucial role in wine production and exports. Both contributions are novel to the scientific literature, improving our understanding of the differences between cooperatives and IOFs and having concrete implications for firms and policymakers.

The paper is structured as follows. In the next section, we present the theoretical background for our research. Next, we illustrate the characteristics of our sample and the related methodology of investigation. Then, we present and examine the results. Finally, we discuss the implications of the findings and our consequent conclusions. 


\section{Theoretical background and research hypothesis}

Economic theory has justified the existence of cooperative organizations due to asymmetries that affect the relationships amongst economic operators in the market (Bijman and Hendrikse, 2003). Specifically, the cooperative movement began in the early 19th century, primarily in the United Kingdom and France, to bundle the purchasing power or productive abilities of many small members (Storchmann, 2018).

The role of this form of economic organization has been particularly significant in the agricultural industry, in which cooperatives aim to respond to market failures and to facilitate market access for individual producers, especially when small in size (Höhler and Kühl, 2014). The fragmentation and pulverization of production amongst thousands of small-scale enterprises make it difficult for individual producers to access the market.

Cooperatives allow us for the achievement economic advantages by aggregating small businesses or individual operators, hence overcoming the difficulties that they may encounter in the procurement of resources, production or the sale of goods and services. Moreover, since cooperatives allow dimensional economies to be achieved, they contribute to better managing information asymmetries amongst operators along the supply chain and therefore of imbalances of power in buyer-seller relations (Hendrikse and Veerman, 2001); for instance, agricultural cooperatives allow individual producers to achieve higher prices than those obtainable by selling their products individually on the market (Chiodo and Ammassari, 2008).

However, the benefits that cooperative members may enjoy from this form of organization are much broader, since cooperatives can also improve the quality of production through the provision of consultancy activities and training opportunities to their members, the pooling of innovations and the hiring of qualified personnel, helping individual members improve their products (Kalogeras et al., 2009).

Notably, the benefits of cooperatives are strictly dependent on the ability of their members to behave in line with cooperative aims (Iliopoulos, 2003); thus, the market success of cooperatives depends on members' behaviours towards them, namely, on members' propensity to invest equity capital in the organizations, members' commitment in participating in corporate life and the quality and quantity of raw materials offered to cooperatives (Kalogeras et al, 2009). In other words, the institutional setting of cooperatives, with the related weaknesses of proprietary rights dominated by the one-person-one-vote principle and the limits on profits distribution, increase the risk of opportunistic behaviours from members, such as the following:

(1) The maximization of individual profit opportunities at the expense of the cooperative organization, such as, through arbitrage in selling raw materials on the market when conditions are favourable and conferring to the cooperative when this guarantees better conditions.

(2) A lack of guaranteeing minimum quality levels of raw materials, especially when this requires considerable effort and commitment from members, considering the potentially automatic purchase of the cooperative.

(3) An unwillingness to provide sufficient equity to finance the organization or to renounce the profits generated to self-finance the cooperative.

(4) Issues arising from coalitions of members who can extract private benefits from the cooperative to the detriment of the organization and other members. This risk is the result of the fragmentation of ownership and the one-person-one-vote mechanism, which may feed free riding behaviours on behalf of cooperative members (Vitaliano, 1983; Hart and Moore, 1998; Borgen, 2004).

Based on the strengths and weaknesses of the cooperative model relative to IOFs, the scientific literature has long discussed differences in the performance of these two models.

Cooperatives' performance in the wine sector 
BFJ

124,13

The results, however, do not offer unambiguous responses, especially with reference to the agri-food sector and wine sectors more specifically, which is the focus of this study.

A line of research, for example, focusses on the analysis of the efficiency of cooperatives compared that of IOFs; in this respect, Porter and Scully (1987) analysed a sample of companies operating in the American dairy sector and highlighted how cooperatives are less efficient than other companies. In contrast, Akridge and Hertel (1992) analysed a sample of companies located in the Midwest of the USA operating in the cereal sector and in services offered to agricultural enterprises, finding that cooperatives are not less efficient than other types of companies; similarly, Sexton and Iskow (1993) find no significant evidence to suggest that cooperatives are less efficient.

Another stream of research has investigated the differences between cooperatives and joint-stock companies using financial ratios; again, the results are mixed. Some studies, for example, suggest that cooperatives have lower profitability than IOFs (Notta and Vlachvei, 2007; Soboh et al., 2011); this difference is due to the institutional characteristics of the cooperative model and its objective, namely, the maximization of the benefits and well-being of members.

In the agricultural sector more specifically, the cost of the procurement of cooperatives is expected to be on average higher than that of IOFs, since suppliers should be members to be paid at higher prices (Guzmán and Arcas, 2008; Hernández-Espallardo et al., 2013; Soboh et al., 2009, 2012). Consequently, cooperatives should have lower profitability because some of their profits are somehow distributed to members with the payment of higher prices for supplied raw materials (Soboh et al., 2009, 2012).

However, other studies, such as those mentioned above, have shown that cooperatives are not less profitable than IOFs (Gentzoglanis, 1997; Boyle, 2004; Hardesty and Salgia, 2004; Lerman and Parliament, 1990). Boyle (2004), for example, analysed the behaviour of cooperatives in the dairy sector and pointed out that cooperatives, in setting the prices of raw materials, behave as if they are maximizing profits, therefore showing no differences from IOFs, whereas Hardesty and Salgia (2004) compared rates of profitability, liquidity, leverage and efficiency in the use of capital in four sectors of the American agri-food industry and found that while cooperatives are less indebted and less efficient, no difference exists relative to other companies in terms of to profitability and liquidity.

Lerman and Parliament (1990) investigated a sample of companies operating in the agricultural and milk sectors in the period of 1976-1987 and highlighted that, contrary to expectations, cooperatives in both sectors perform the same as or better than IOFs in terms of profitability and financial and interest coverage. Accordingly, the authors suggest that cooperatives could pursue the same goals of those of IOFs, noting that the widespread standards of financial analysis in the business community may have forced cooperatives to adopt the same objectives as those of IOFs in practice.

Therefore, given this ambiguous evidence in the literature, which can represent an intriguing gap to explore, the extent to which cooperatives can perform better than IOFs is the scope of the current research; naturally, as the presence of cooperatives in all economies and especially in the agri-food sector is so vast, as mentioned above, it was necessary to detect a specific context of investigation to pursue this goal. In the agricultural sector, Italy has a large and well-developed system of cooperatives that play a relevant role, as they produce more than a third of the total agricultural production; approximately 5,000 cooperatives operate in Italy, with a total turnover of approximately 40 billion euros and more than 90,000 employees (Italian Agricultural Cooperation Observatory, 2017; Fusco and Migliaccio, 2019).

More specifically, the Italian wine sector, our specific unit of investigation, includes approximately 500 cooperatives with more than 9,000 employees. These cooperatives are responsible for almost $60 \%$ of wine produced and for almost $45 \%$ of the entire turnover, contributing a third of wine exports. 
More generally, in 2018, i.e. the last year of the period under investigation in the current research, Italy recovered high quantitative levels of wine production, which experienced considerable decline in 2017 due to various climatic difficulties, such as frost and droughts; the 2018 Italian harvest amounted to more than 50 million hectolitres, confirming the status of Italy as a leading country amongst wine producers. At the same time, Italy ranks second in the volume of wine exports (after Spain) and second in the value of wine exports (after France) (we draw these data from the International Organization of Vine and Wine [OIV]), www.oiv. int, 2019 and 2020).

Therefore, we contend that the Italian wine sector represents a very interesting context as a sort of extreme case (Eisenhardt, 1989) for analysing the differences between cooperatives and IOFs. Moreover, recent empirical evidence shows that in the Italian wine sector, cooperatives are fundamental not only from an economic point of view in terms of wine production and turnover but also from the social perspective of protecting and safeguarding the territory (Italian Agricultural Cooperation Observatory, 2017); rather, a positive relationship has been highlighted between the presence of cooperatives and the growth of vineyard surfaces. In contrast, in territories where cooperatives are absent or where few small cooperatives operate, a decrease in the surface of vineyards has been observed.

Thus, focussing on the Italian wine sector and adopting a measure of performance not distorted by the objectives of cooperatives, the research hypothesis under analysis is as follows:

H1. Cooperatives in the Italian wine sector globally perform better than IOFs.

\section{Research design: the sample}

In this study, we adopted a panel approach to investigate a sample of firms operating in the Italian wine sector from 2009 to 2018 to provide evidence on whether and to what extent cooperatives differ in their results from those of IOFs, mainly in the forms of joint-stock and limited liability companies. The time interval was determined to examine a normal scenario without potential bias deriving from the COVID-19 pandemic (balance approval for 2019 would have occurred in 2020, with the pandemic already in progress).

The sample was selected from the Bureau van Dijk AIDA database, which contains demographic information and financial data on approximately 600,000 Italian firms; the selection of firms was done according to the EU-NACE (Nomenclature statistique des activités économiques) code onding to the production of wine. We excluded firms in liquidation and/or subject to bankruptcy procedures and therefore those with negative equity because they are insolvent; furthermore, we eliminated firms established as partnerships or sole proprietorships.

Such exclusion was necessary to guarantee the reliability and comparability of the accounting data of the sampled firms; in fact, partnerships as well as sole proprietorships could present exceptions or simplifications in the preparation of financial statements that could reduce the comparability of such data for other types of firms. Finally, companies without financial data for the period under analysis were eliminated, i.e. those established in 2017 or 2018 or without observations for at least two consecutive years.

As a result, the final sample includes 1,171 Italian wine firms operating during the 2009-2018 period. Data were collected from annual financial statements extracted from the AIDA database, returning a highly balanced panel of 11,502 observations. Our data set is likely one of the most comprehensive on Italian wine firms and likely one of the most specific for exploring differences in the performance of cooperatives and IOFs in the Italian wine industry.

\section{Research design: dependent and independent variables}

To investigate whether cooperatives perform better than IOFs, we assumed that these two types of companies differ in their objectives and ownership structures; in IOFs, ownership is 
$\mathrm{BFJ}$

124,13

assigned to risk capital holders who act as residual claimants, while in cooperatives, ownership is assigned to the same subjects for whose interest the business is assigned, where these subjects are involved as customers or workers or as suppliers of raw materials (as in wine cooperatives) (Chaddad and Cook, 2004). Consequently, while the former aim at maximizing profits, the latter is committed to pursuing the interests of members as customers, workers or suppliers (Cook, 1995).

In the wine industry more specifically, cooperatives aim to purchase grapes from their members, usually small growers, under better conditions compared to those of the market; thus, the benefit for cooperative members is not represented by the as-it-were profit but by the higher prices achieved by selling grapes to the cooperative. Consequently, the cooperative's margin is distorted because the costs of raw materials are higher than those that any other similar company that purchases grapes on the market could incur.

Given these considerations and adopting the approach proposed by Borzaga and Fontanari (2014), in this study, we measured firm performance with an adjusted measure based on the EBITDA gross the cost of raw materials as follows:

$$
\frac{\text { EBITDA }_{i, t}+\text { Cost of raw materials }_{i, t}}{\text { Revenue }_{i, t}}
$$

where the $i$ and $t$ indices refer to the $i$-th company and $t$-th year, respectively. This measure, without distortion due to the cost of raw materials, could emerge as a useful indicator for comparing the different types of firms operating in the wine sector.

The independent variable used in the analysis is a dummy variable that assumes a value of 0 if firm $i$ in year $t$ is an IOF (a joint-stock or limited company) and 1 if the firms is a cooperative. To avoid spurious relationships, we controlled for some firm-level variables that could affect performance; more specifically, we controlled for the following parameters:

(1) The size of the firm is a key variable affecting corporate competitiveness and the management of relationships with various stakeholders (Hall and Weiss, 1967; Lee, 2009). Size is expressed as the natural logarithm of total assets.

(2) The age of the firm as a proxy of corporate experience and visibility in the market. Older firms have a more stable competitive position, and they create fewer information asymmetry problems for stakeholders (Stinchcombe, 2000; Coad et al., 2013). This variable was measured as the natural logarithm of the difference between year $t$ and the date of incorporation of the company.

(3) Financial leverage is the natural logarithm of the debt/equity ratio. Some scientific literature has shown that debt influences corporate performance in different ways (Weill, 2008; González, 2013). From the agency theory perspective, debt stimulates managers to perform better; from the trade-off theory perspective, debt generates contrasting effects, since it is a source of benefits and increases bankruptcy costs.

(4) The incidence of tangible fixed assets of total assets. The proportion of tangible fixed assets is a proxy of the firm's rigidity/flexibility and therefore of its operational risk (Deloof, 2003; Weill, 2008).

(5) Growth of the firm as the change in total assets in period of $t-1$ to $t$. This variable is a proxy of the growth opportunities of the firm (MacMillan and Day, 1987; Markman and Gartner, 2002).

(6) The liquidity conditions of the firm are the proportion of liquid assets to total assets (Deloof, 2003; Ross et al., 2000). 
Furthermore, we considered the characteristics of wine production in the areas where the sampled firms are located; the performance of a given firm, especially in the case of a winery, could be affected by the reputation of the territory in which it is located (Vrontis et al., 2016) and therefore by terroir, a concept that identifies the geological, climatic and social conditions of a defined geographic area. This variable was operationalized as the ratio for the year $t$ of the produced amount of wine with a designation of origin (DO) (as the protected denomination of origin [PDO] or protected geographical indication [PGI]) to the total amount of wine produced in the region where the company is located.

Fixed effects at the geographic level were included to consider time-invariant differences at the macroeconomic and contextual levels between the different Italian geographic areas; in this respect, we added four dummies for the north-western, central, south and island macro-regions and set the north-eastern region was the reference category. Finally, time fixed effects were included to consider changes in economic and contextual conditions occurring over time.

\section{Summary statistics}

Regarding the composition of the sample and the descriptive statistics of the variables used in the analysis, Table 1 analyses the sample by firm type (IOF or cooperative) and geographic settlement, both with reference to the macro-region of reference in this study, as mentioned above (i.e. the north-eastern region), and to the region of location.

As expected, the regions that are most represented include Veneto, Apulia, Tuscany, Sicily and Piedmont and Emilia-Romagna in descending order, which globally speak are the main wine-producing regions in Italy. Regarding institutional settings, the most common are firms established as IOFs with an incidence of $73.6 \%(862 / 1,171)$, while cooperatives account for $26.4 \%(309 / 1,171)$.

Table 2 shows the main descriptive statistics for the variables under analysis. Regarding the potential wine-contextualized indicators (firm performance, tangible fixed assets and

\begin{tabular}{llrrr}
\hline Macro-region & Region & IOFs & Cooperatives & Total \\
\hline \multirow{2}{*}{ North-western } & Valle d'Aosta & 3 & - & 3 \\
& Piedmont & 57 & 30 & 87 \\
& Liguria & 2 & 2 & 4 \\
North-eastern & Lombardy & 66 & 11 & 77 \\
& Trentino-A.A. & 25 & 27 & 52 \\
& Veneto & 151 & 33 & 184 \\
Central & Friuli-V.G. & 33 & 5 & 38 \\
& Emilia-Romagna & 53 & 29 & 82 \\
& Tuscany & 140 & 13 & 153 \\
& Umbria & 10 & 6 & 16 \\
Southern & The Marche & 24 & 9 & 33 \\
& Lazio & 27 & 6 & 33 \\
& Abruzzi & 28 & 30 & 58 \\
& Molise & 2 & 2 & 43 \\
Tsland & Campania & 29 & 4 & 159 \\
& Apulia & 121 & 38 & 4 \\
Total & Basilicata & 2 & 2 & 12 \\
Calabria & 9 & 3 & 36 \\
& Sicily & 66 & 37 & 1,171
\end{tabular}

Source(s): Authors' calculations
Cooperatives' performance in the wine sector 
$\mathrm{BFJ}$ 124,13

\section{2}

Table 2.

Descriptive statistics of the variables under analysis

wines with DOs/total wines), the observations show low levels of dispersion, and dispersion is higher for the other indicators concerning common business (except for the growth rate).

For each variable under analysis, Table 3 shows the results of the $t$-test for the difference in means between the group of firms established as IOFs and the group of cooperatives. The differences between the two types of institutional settings are highly significant, with cooperatives showing stronger performance in terms of the ratio between EBITDA gross the cost of raw materials and revenues; furthermore, cooperatives are on average older than IOFs $(t=-46.85, p<0.1 \%)$ and larger in size $(t=-1.913, p<5 \%)$, confirming that in the agricultural sector particularly and in the wine sector more specifically, they are a wellestablished phenomenon (Stiglitz, 2004; Zamagni, 2005).

On average, cooperatives belonging to the sample are 47 years old, while the IOFs are approximately 20 years old; cooperatives are less indebted $(t=5.59, p<0.1 \%)$ and have a smaller proportion of tangible fixed assets $(t=9.98, p<0.1 \%)$. The lower level of indebtedness found for cooperatives seems to be in line with the scientific literature, which suggests the existence of agency problems with lenders who are more severe than what is found in other types of companies; in cooperatives, the weaknesses of property rights increase members' incentives to free-ride and be less committed to their cooperatives (Schlicht and von Weizsäcker, 1977; Cook, 1995), creating higher cost of debt and greater credit rationing problems (Drèze, 1993; Putterman, 1993; Dow, 2003) and potentially discouraging to exploitation of financial leverage.

The lower debt exposure in cooperatives could also be explained by a time horizon problem related to the goals pursued by cooperative members, as they may not be willing to invest in their

\begin{tabular}{lrrrr}
\hline Variable & \multicolumn{1}{c}{ Mean } & Std. dev. & \multicolumn{1}{c}{ Min. } & \multicolumn{1}{c}{ Max. } \\
\hline Firm performance & 0.850 & 0.177 & 0.398 & 1.481 \\
Firm size (€/000) & $15,035.420$ & $30,571.260$ & 0.428 & $655,066.400$ \\
Firm age & 27.290 & 22.840 & 0.000 & 125.000 \\
Financial leverage (D/E) & 1.740 & 2.690 & 0.000 & 12.290 \\
Tangible fixed assets (\%) & 0.370 & 0.260 & 0.000 & 0.999 \\
Growth rate (\%) & 0.071 & 0.162 & -0.185 & 0.710 \\
Liquidity ratio & 0.940 & 0.980 & 0.000 & 9.960 \\
Wines with DOs/total wines (\%) & 0.450 & 0.250 & 0.030 & 0.950 \\
Source(s): Authors' calculations & & & & \\
\hline
\end{tabular}

Table 3.

Univariate test for the analysis of average differences between IOFs and cooperatives

\begin{tabular}{lccc}
\hline Variable & IOFs & Cooperatives & $t$-stat \\
\hline Firm performance & 0.819 & 0.923 & $-26.05^{* * * *}$ \\
Firm size $(h)$ & 8.928 & 8.941 & $-1.913^{*}$ \\
Firm age $(h)$ & 2.930 & 3.800 & $-46.85^{* * *}$ \\
Financial leverage $(l h)$ & 0.756 & 0.653 & $5.59^{* * *}$ \\
Tangible fixed assets $(\%)$ & 0.385 & 0.334 & $9.98^{* * *}$ \\
Growth rate $(\%)$ & 0.074 & 0.048 & $7.23^{* * *}$ \\
Liquidity ratio & 1.006 & 0.792 & $9.20^{* * *}$ \\
Wines with DOs/total wines & 0.469 & 0.456 & 0.93 \\
No. of obs. & 8,424 & 3,078 & \\
No. of firms & 862 & 309 &
\end{tabular}

Note(s): $*$ and $* * *$ denote significance at 5 and $0.1 \%$, respectively. If not specified, there is no statistical significance

Source(s): Authors' calculations 
cooperatives for a long time in an aim to achieve short-term benefits. Therefore, cooperatives adopt conservative policies by assuming less risk and therefore using self-financing instead of debt as their main source of financial resources (Soboh et al., 2011).

Regarding the lower level of fixed assets found, this evidence seems to be the result of the business model used by these organizations, given that they purchase almost all raw materials from their members with limited or even no investments in vineyards. Lower levels of debt and fixed assets suggest that cooperatives are subject to less financial and operational risk, confirming that cooperatives are in general less risky than IOFs.

On average, cooperatives show lower growth rates $(t=7.23, p<0.1 \%)$ in terms of total assets, whereas cooperatives have an average growth rate of revenues equal to $8.6 \%$ vs a value of $12.8 \%$ for IOFs. This could be the result of the constraints on growth that affect cooperatives given the characteristics of their institutional setting and their overall mission such as the production of specific goods and/or distribution to specific areas (Rhodes, 1983).

Finally, a lower level of liquidity characterizes cooperatives $(t=9.20, p<0.1 \%)$; this result is also reported in the scientific literature (Royer, 1991; Gentzoglanis, 1997; Fazzini and Russo, 2014) and could be explained by the fact that cooperative members exert pressure on their cooperatives to maximize their monetary benefits by, for example, increasing the price of raw materials conferred to their cooperatives and consequently absorbing the liquid assets of the cooperatives (Hardesty and Salgia, 2004). Other studies attribute this result to cooperatives excessively investing in their inventory, thus reducing their level of liquidity (Lerman and Parliament, 1990; Gentzoglanis, 1997).

Table 4 shows the correlation matrix (Pearson coefficients). The correlation coefficients are quite low, suggesting that multicollinearity problems in the proposed models are modest.

The correlation coefficients confirm previous results. More specifically, there is a positive correlation between the cooperative form and the adjusted measure of firm performance $(\rho=0.257, p<0.1 \%)$, size $(\rho=0.019, p<10 \%)$ and age $(\rho=0.413, p<0.1 \%)$. Thus, cooperatives are increasingly larger and older and perform better as per the adjusted EBITDA margin; furthermore, cooperatives are less indebted $(\rho=-0.061, p<0.1 \%)$, have a lower incidence of tangible assets $(\rho=-0.023, p<5 \%)$, lower growth rates $(\rho=-0.078$, $p<0.1 \%)$ and lower levels of liquidity $(\rho=-0.093, p<0.1 \%)$.

Figure 1 shows the average values of performance (as per the adjusted EBITDA) for IOFs and cooperatives for the period under investigation. From the above secondary data, although at only the descriptive level, cooperatives have performed better, providing initial evidence in support of $\mathrm{H} 1$; in the following section, the statistical robustness of this evidence is analysed.

\section{Regression statistics and consequent results discussion}

To investigate whether cooperatives achieve stronger performance than IOFs, the following model is estimated:

$$
\text { Performance }_{i, t}=a_{j}+\lambda_{t}+\beta \text { Cooperative }_{i, t}+\gamma Z_{i, t}+\varepsilon_{i, t}
$$

The dependent variable is measured as the ratio between EBITDA (adjusted for the cost of raw materials) and revenues; on the right side of the equation, $a_{j}$ and $\lambda_{t}$ are fixed effects at the regional and year levels, respectively; $Z_{i, t}$ is a vector of control variables; $\varepsilon_{i, t}$ is the error term; and $\beta$ is the coefficient of interest. A random effects panel approach was used to estimate Model (1); the Breusch-Pagan Lagrange multiplier (LM) test excluded a pooled ordinary least squares (OLS) approach, and because the variable that defines the institutional setting of a firm (cooperative) is time-invariant, a fixed effects approach was used to estimate Model (1).

The model was engineered using robust clustered standard errors at the firm level. To mitigate the impact of outliers, all variables with extreme values are "winsorized" at the 1 and $99 \%$ levels.
Cooperatives' performance in the wine sector

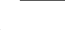


BFJ

124,13

44

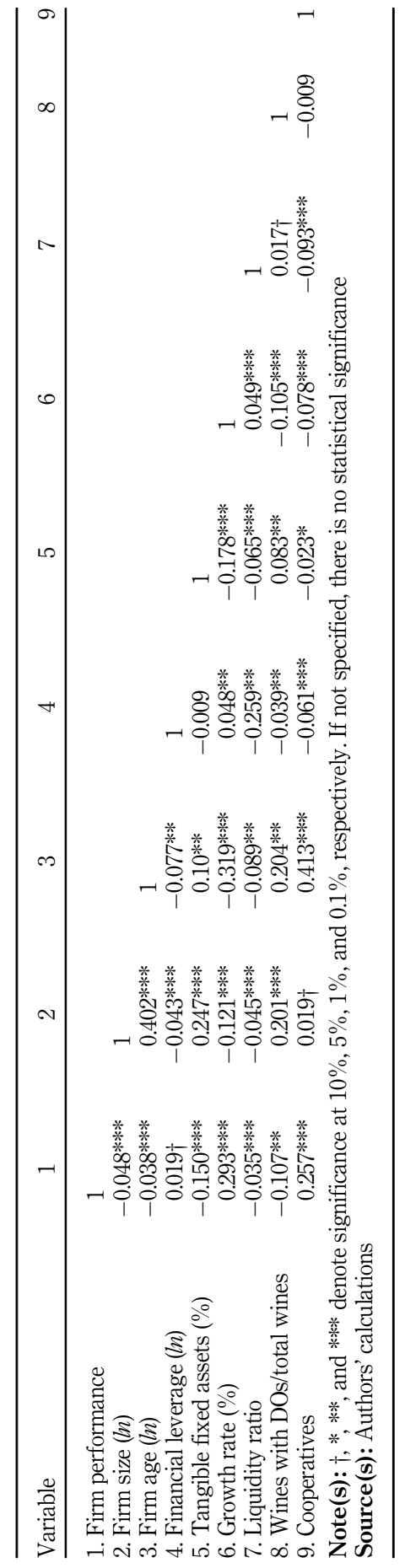

Table 4.

Correlation matrix Pearson coefficients 


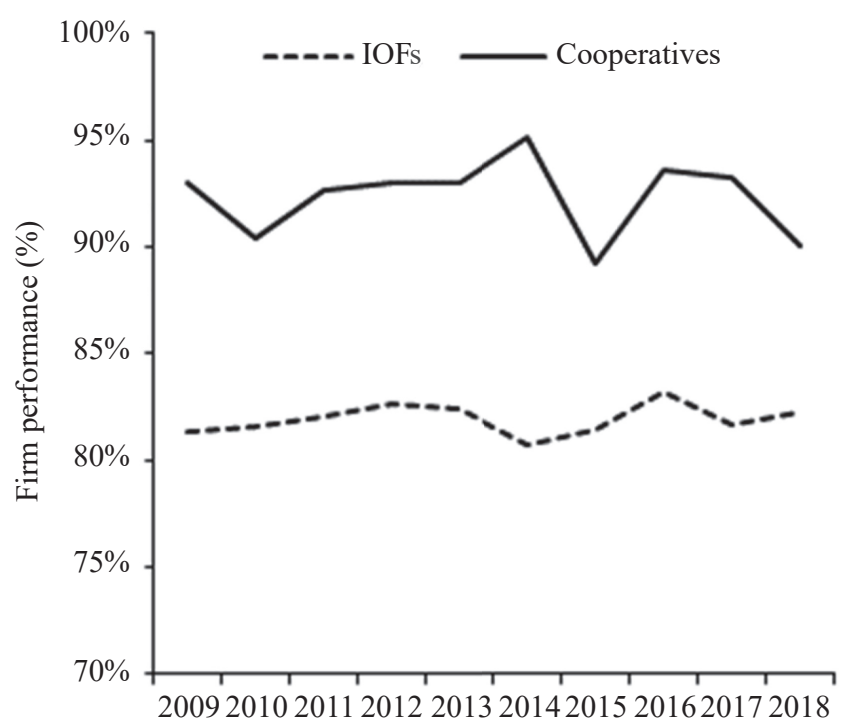

Cooperatives' performance in the wine sector

Source(s): Authors' calculations

Figure 1. Annual mean performance (adjusted EBITDA) for IOFs and cooperatives from 2009

to 2018

Regarding endogeneity, which is a recurring problem in managerial and financial research concerning the link between firm performance and firm governance and/or ownership structure, in this setting, it is mitigated by the source and construction of the independent variable; more specifically, independent variable "cooperative" is treated as exogenous to performance (Gorton and Schmid, 1999). Although firms are free to use the optimal ownership structure for them or adapt it to their needs, the use of the cooperative model as an alternative to other institutional settings can be attributable to the specific objectives that members pursue and not to the level of firm performance; moreover, in the data set under analysis, the dummy variable for cooperative status is time invariant, and thus, there is no simultaneity bias between the institutional setting of a firm and its performance. However, to avoid problems of simultaneity between the dependent variable and the level of debt and liquidity of a company, the latter is included in the model lagged by one year.

Table 5 presents the results of regression Model (1), which appear to be statistically significant; more specifically, the control variables have the expected signs. For the variable of interest, the cooperative organization is positively and significantly associated with the level of economic performance $(\beta=0.115, p<0.1 \%)$, supporting $\mathrm{H} 1$; therefore, on average, cooperatives have stronger performance than IOFs, confirming that a cooperative is not a marginal organization of economic production doomed to inefficiency but can represent a model that can perform in line with or even better than other types of firm institutions.

More specifically, Column 1 of Table 5 shows that performance is positively associated with firm size $(\beta=0.011, p<0.1 \%)$; this result is overall coherent with the relevance, in the wine industry, of dimensional economies; a large firm size greatly affects firm performance and hence firm survival. Furthermore, the economic result is positively associated with the level of debt $(\beta=0.015, p<0.1 \%)$, growth opportunities $(\beta=0.285, p<0.1 \%)$ and the level of liquidity $(\beta=0.009, p<5 \%)$; in contrast, the economic result is negatively associated with the incidence of tangible assets $(\beta=-0.056, p<0.1 \%)$, whereas the association with age $(\beta=-0.005)$ is not statistically significant. 


\section{$\mathrm{BFJ}$ 124,13}

Table 5.

Results of the regression model

\begin{tabular}{|c|c|c|c|}
\hline Variable & 1 & 2 & 3 \\
\hline Firm size $(h)$ & $0.011^{* * * *}(3.77)$ & $0.011 * * *(3.86)$ & $0.011^{* * *}(3.77)$ \\
\hline Firm age $(m)$ & $-0.005(-1.01)$ & $-0.005(-1.01)$ & $-0.003(-0.71)$ \\
\hline Financial leverage $_{(t-1)}(\mathrm{ln})$ & $0.015^{* * * *}(3.32)$ & $0.015 * * *(3.36)$ & $0.016 * * * *(3.54)$ \\
\hline Tangible fixed assets (\%) & $-0.056 * * *(-3.66)$ & $-0.056 * * *(-3.73)$ & $-0.057 * * *(-3.85)$ \\
\hline Growth rate $(\%)$ & $0.285^{* * * *}(17.32)$ & $0.284 * * *(17.31)$ & $0.285^{* * * *}(17.35)$ \\
\hline Liquidity ratio $(t-1)$ & $0.009 *(2.54)$ & $0.009 *(2.55)$ & $0.009 * *(2.58)$ \\
\hline Wines with DOs/total wines & $-0.025 \dagger(-1.72)$ & $-0.042 *(-2.46)$ & $-0.020(-1.38)$ \\
\hline Cooperatives & $0.115^{* * * *}(15.38)$ & $0.093 * * *(7.44)$ & $0.134^{* * * *}(11.08)$ \\
\hline North-western & $-0.026 *(-2.51)$ & $-0.026 *(-2.46)$ & $-0.030 *(-2.38)$ \\
\hline Central & $-0.034 * * * *(-3.75)$ & $-0.032 * * *(-3.61)$ & $-0.036 * * *(-3.43)$ \\
\hline Southern & $0.015(1.15)$ & $0.014(1.04)$ & $0.031 *(2.04)$ \\
\hline Island & $-0.009(-0.72)$ & $-0.009(-0.71)$ & $0.038 *(2.24)$ \\
\hline $\begin{array}{l}\text { Cooperatives } \times \text { Wines with DOs/total wines } \\
\text { (Northeast) }\end{array}$ & & $0.049 *(2.38)$ & \\
\hline Cooperatives $\times$ North-western & & & $0.009(0.43)$ \\
\hline Cooperatives $\times$ Central & & & $0.012(0.73)$ \\
\hline Cooperatives $\times$ Southern & & & $-0.050 *(-2.35)$ \\
\hline Cooperatives $\times$ Island & & & $-0.117 * * *(-5.38)$ \\
\hline Intercept & $0.731 * * * *(24.60)$ & $0.736 * * *(24.75)$ & $0.720 * * *(24.22)$ \\
\hline Year FE & Yes & Yes & Yes \\
\hline No. & 7,363 & 7,363 & 7,363 \\
\hline Wald $\chi^{2}$ & 763.1 & 770.1 & 831.4 \\
\hline$R^{2}$ & 0.199 & 0.202 & 0.214 \\
\hline Breusch-Pagan (LM) test & $3,606.48 * * *$ & $3,557.77 * * *$ & $3,394.93 * * *$ \\
\hline
\end{tabular}

Note(s): $\dagger, * * *$ and $* * *$ denote significance at $10 \%, 5 \%, 1 \%$ and $0.1 \%$, respectively. If not specified, there is no statistical significance

Source(s): Authors' calculations

To analyse this research outcomes in greater detail, further estimations were carried out to verify whether the positive association between cooperative form and performance is moderated by variables at the geographic level, i.e. whether this relationship behaves differently when geographic-level variables are considered. First, we tested (Column 2 of Table 5) whether this relationship depends on the reputation of the territory in which a firm operates (expressed by the proportion of wine with DOs of the amount of wine produced in the area where a company is located); the results listed in Column $2(\beta=0.049, p<5 \%)$ suggest the existence of a moderating effect of the reputation of the territory on the relationship between the cooperative form and economic performance, i.e. cooperatives operating in highly renowned territories show stronger performance than noncooperative firms operating in highly renowned territories.

Second, in Column 3 of Table 5, we also analysed the moderating effect of the geographic area where a firm is located on the relationship between the cooperative form and performance; the results indicate that while cooperatives operating in north-western and central Italy do not present significant differences from those operating in the north-eastern region (the reference category of the current analysis), those that operate in the southern $(\beta=-0.05, p<5 \%)$ and island regions $(\beta=-0.117, p<0.1 \%)$ show a lower level of performance than cooperatives in the north-eastern region. This evidence likely shows that cooperatives located in southern Italy and even more so in island region have less effective and efficient organizational characteristics than those in the north-eastern region, where cooperatives have longer traditions, are better established and are committed to developing an effective networking strategy amongst private and public actors for the promotion of the wine industry (Bresciani, 2017). 


\section{Theoretical and managerial implications}

The results of the present research seem to contribute to the literature on cooperatives in several ways. First and most of all, based on the peculiar characteristics of the cooperative model and in line with a specific stream of the scientific literature, as aforementioned in the theoretical section of this study, we empirically demonstrate that cooperatives can perform (adopting the adjusted EBITDA as a measure of performance) similarly to, if not better than, firms established as IOFs.

Furthermore, compared to other research on cooperative performance, this research seems to be distinct from both a theoretical and methodological point of view, because while the main scientific literature on cooperatives extensively adopts classical financial performance measures as a proxy for the effectiveness of the cooperative model, we examine whether cooperatives differ from IOFs from the objectives they pursue, and therefore, we use a non-distorted measure of performance to explore whether profit maximization is not the main goal of cooperatives.

Despite the theoretical literature suggesting that the cooperative forms of organizations suffer many weaknesses due to their peculiar ownership structures and the rights granted to their members, in hypothesizing that they perform worse than IOFs, we demonstrate that cooperatives are at least as economically efficient as other forms of economic organizations, such as for-profit firms. Not only does our empirical evidence suggest that cooperatives perform better than IOFs, but we also highlight that cooperatives located in the southern and island regions of Italy perform worse than those located in northern Italy, where cooperatives have been well established for a longer time.

Regarding managerial implications, the present research highlights that the cooperative model is an effective form for organizing production in the wine sector; this result should encourage the use of this organizational form in a sector dominated by the fragmentation of grape production amongst many small farmers, especially in Italy. In line with relevant scientific literature in the field, to increase the likelihood of this model fully expressing its potential in terms of economic and social performance (also more generally for the food and wine sectors and not only for cooperatives: Bresciani et al., 2016a; Giacosa et al., 2017; Cantino et al., 2019; De Bernardi et al., 2020; Nirino et al., 2020), it seems necessary for cooperatives to be oriented towards the continuous improvement of some key issues as follows:

(1) Governance profiles: The governance of cooperatives based in one-person-one-vote and self-government principles with management entrusted to members has advantages and limitations. Specific attention must be directed to strengthening the governance structure by adopting measures that, while preserving cooperative values and the benefits of member participation, can reduce the limits of the model (Bijman et al., 2013; Hakelius, 2018).

(2) Strategic approach: The vision of the future and therefore the search for the best development opportunities are fundamental to motivating cooperative members towards ambitious goals and attracting new resources to cooperatives (Bretos and Marcuello, 2017).

(3) Quality management systems and production sustainability: Quality and sustainability are key factors that affect global competition; therefore, taking care of the producers of raw materials is imperative and implies the strengthening of relationships with members (Bareille et al., 2017).

(4) Systems for involving cooperative members: This issue, which is related to the problem of governance, is aimed at managing the conflicts of interest between a cooperative and its members and preventing opportunistic behaviours. The involvement of members through discussions of community opportunities is essential to keep alive the
Cooperatives' performance in the wine sector 
BFJ

124,13 cooperative spirit and, above all, an awareness of the benefits that cooperatives guarantee their members and the communities in which they operate (Iliopoulos, 2003).

\section{Research limitations and avenues for future research}

The results of the current investigation seem relevant both for management theory and practice; however, they may lack straightforward generalizability, as our research hypothesis was tested on a sample of Italian wine firms for a 10-year period (2009-2018). Therefore, extending the present study to include additional firms from other countries and expanding the period of observation would enhance the generalizability and usefulness of the current findings.

Additionally, increasing the number of sources from which data are extracted (i.e. considering not only the Bureau van Dijk AIDA database) could reinforce the global validity and reliability of the present study. As every database is subject to several conditions of data entry, other sources could us provide data on other companies, increasing the variety and number of observations considered (as is shown, for example, in Bresciani et al., 2016b).

Beyond strict reference to the structural characteristics of the current investigation, the results of the present research were intentionally calculated without potential bias deriving from the COVID-19 pandemic. Instead, evidence emerging from 2020 and following years could and probably would delineate different situations, also with regard to new forms of wine consumption (Acuti et al., 2020), but quite likely the cooperatives should perform even better due to their limited relationship to hotel, restaurant, café/catering (Ho.Re.Ca.) distribution channel (which experienced broad closures during the pandemic), at least with respect to "standard" IOFs, thus creating a need to test the results of the current research in the new context of the COVID-19 pandemic and in continuous evolution with the associated vaccine campaign.

\section{Conclusion}

Although they have often been considered less efficient organizations with relative to IOFs, cooperatives represent a vital economic model, which from the current investigation has emerged even as more efficient. Naturally, this evidence remains contextualized in our realm of analysis, i.e. the Italian wine sector, with a specific focus on the north-eastern area.

This result also seems fruitful because it is the outcome of a procedure adopting an adjusted indicator, i.e. EBITDA plus the cost of raw materials on revenues. On the one hand, this seems a relevant innovation for evaluating the real economic efficiency of (wine) cooperatives, and on the other hand, the parameter at the end measures overall performance for members and not only for cooperatives, providing new insight into the subject and requiring further development through future analysis.

\section{References}

Acuti, D., Mazzoli, V., Grazzini, L. and Rinaldi, R. (2020), "New patterns in wine consumption: the wine by the glass trend", British Food Journal, Vol. 122 No. 8, pp. 2655-2669.

Akridge, J.T. and Hertel, T.W. (1992), "Cooperative and investor-oriented firm efficiency: a multiproduct analysis", Journal of Agricultural Cooperation, Vol. 7 No. 1992, pp. 1-14.

Bareille, F., Bonnet-Beaugrand, F. and Duvaleix-Tréguer, S. (2017), "Objectives' alignment between members and agricultural cooperatives", Review of Agricultural, Food and Environmental Studies, Vol. 98 Nos 1-2, pp. 75-91.

Bijman, J. and Hendrikse, G. (2003), "Co-operatives in chains: institutional restructuring in the Dutch fruit and vegetable industry", Journal on Chain and Network Science, Vol. 3 No. 2, pp. 95-107. 
Bijman, J., Hendrikse, G. and van Oijen, A. (2013), “Accommodating two worlds in one organisation: changing board models in agricultural cooperatives", Managerial and Decision Economics, Vol. 34 Nos 3-5, pp. 204-217.

Birchall, J. and Ketilson, L.H. (2009), "Resilience of the cooperative business model in times of crisis", International Labour Organisation, pp. 1-41, available at: https:/www.ilo.org/wcmsp5/groups/ public/_ed_emp/—emp_ent/documents/publication/wcms_108416.pdf (accessed 15 March 2021).

Bonus, H. (1986), "The cooperative association as a business enterprise: a study in the economics of transactions", Journal of Institutional and Theoretical Economics, Vol. 142 No. 2, pp. 310-339.

Borgen, S.O. (2004), "Rethinking incentive problems in cooperative organizations", Journal of SocioEconomics, Vol. 33 No. 4, pp. 383-393.

Borzaga, C. and Fontanari, E. (2014), "Le Cooperative Vitivinicole tra Tradizione ed Efficienza: Una Riflessione sul Caso Italiano (Wine Cooperatives between Tradition and Efficiency: considerations on the Italian Case)", Euricse - European Research Institute on Cooperative and Social Enterprises Working Paper N. 64/14, pp. 1-20.

Boyle, G.E. (2004), "The economic efficiency of Irish dairy marketing co-operatives", Agribusiness, Vol. 20 No. 2, pp. 143-153.

Bresciani, S. (2017), "Open, networked and dynamic innovation in the food and beverage industry", British Food Journal, Vol. 119 No. 11, pp. 2290-2293.

Bresciani, S., Ferraris, A., Santoro, G. and Nilsen, H.R. (2016a), "Wine sector: companies' performance and green economy as a means of societal marketing", Journal of Promotion Management, Vol. 22 No. 2, pp. 251-267.

Bresciani, S., Giacosa, E., Broccardo, L. and Culasso, F. (2016b), "The family variable in the French and Italian wine sector", EuroMed Journal of Business, Vol. 11 No. 1, pp. 101-118.

Bretos, I. and Marcuello, C. (2017), "Revisiting globalization challenges and opportunities in the development of cooperatives", Annals of Public and Cooperative Economics, Vol. 88 No. 1, pp. 47-73.

Cantino, V., Giacosa, E. and Cortese, D. (2019), "A sustainable perspective in wine production for common-good management: the case of Fontanafredda biological "reserve"', British Food Journal, Vol. 121 No. 2, pp. 259-274.

Chaddad, F.R. and Cook, M.L. (2004), "Understanding new cooperative models: an ownership-control rights typology", Review of Agricultural Economics, Vol. 26 No. 3, pp. 348-360.

Chiodo, E. and Ammassari, G. (2008), "Il sistema della cooperazione vitivinicola e la riforma della OCM vino", Agriregionieuropa, Vol. 4 No. 12, available at: https://agriregionieuropa.univpm.it/it/ content/article/31/12/il-sistema-della-cooperazione-vitivinicola-e-la-riforma-della-ocm-vino (accessed 15 March 2021).

Coad, A., Segarra, A. and Teruel, M. (2013), "Like milk or wine: does firm performance improve with age?", Structural Change and Economic Dynamics, Vol. 24 No. 1, pp. 173-189.

Cook, M.L. (1995), "The future of U.S. Agricultural cooperatives: a neo-institutional approach", American Journal of Agricultural Economics, Vol. 77 No. 5, pp. 1153-1159.

De Bernardi, P., Bertello, A., Venuti, F. and Foscolo, E. (2020), "How to avoid the tragedy of alternative food networks (AFNs)? The impact of social capital and transparency on AFN performance", British Food Journal, Vol. 122 No. 7, pp. 2171-2186.

Deloof, M. (2003), "Does working capital management affect profitability of Belgian firms?", Journal of Business Finance and Accounting, Vol. 30 Nos 3-4, pp. 573-588.

Dow, G.K. (2003), Governing the Firm: Workers' Control in Theory and Practice, Cambridge University Press, Cambridge, UK.

Drèze, J.H. (1993), "Self-management and economic theory efficiency funding and employment", in Bardhan, P.K. and Roemer, J.E. (Eds), Market Socialism: The Current Debate, Oxford University Press, New York, NY, pp. 253-265. 
BFJ

124,13

Eisenhardt, K.M. (1989), "Building theories from case study research", The Academy of Management Review, Vol. 14 No. 4, pp. 532-550.

Fazzini, M. and Russo, A. (2014), "Profitability in the Italian wine sector: an empirical analysis of cooperatives and investor-owned firms", International Journal of Academic Research in Accounting, Finance and Management Sciences, Vol. 4 No. 3, pp. 130-137.

Fusco, F. and Migliaccio, G. (2019), "Cooperatives and crisis: economic dynamics in Italian context", International Journal of Business and Globalisation, Vol. 22 No. 4, pp. 638-654.

Gentzoglanis, A. (1997), "Economic and financial performance of cooperatives and investor-owned firms: an empirical study", in Nilsson, J. and van Dijk, G. (Eds), Strategies and Structures in the Agro-Food Industries, Van Gorcum and Comp, Assen, pp. 171-183.

Giacosa, E., Ferraris, A. and Monge, F. (2017), "How to strengthen the business model of an Italian family food business", British Food Journal, Vol. 119 No. 11, pp. 2309-2324.

González, V.M. (2013), "Leverage and corporate performance: international evidence”, International Review of Economics and Finance, Vol. 25 No. 2013, pp. 169-184.

Gorton, G. and Schmid, F. (1999), "Corporate governance, ownership dispersion and efficiency: empirical evidence from Austrian cooperative banking", Journal of Corporate Finance, Vol. 5 No. 2, pp. 119-140.

Grashuis, J. and Su, Y. (2019), "A review of the empirical literature on farmer cooperatives: performance, ownership and governance, finance, and member attitude", Annals of Public and Cooperative Economics, Vol. 90 No. 1, pp. 77-102.

Guzmán, I. and Arcas, N. (2008), "The usefulness of accounting information in the measurement of technical efficiency in agricultural cooperatives", Annals of Public and Cooperative Economics, Vol. 79 No. 1, pp. 107-131.

Hakelius, K. (2018), "Understanding the board of Swedish farmer cooperatives - cases focusing on board composition and interaction patterns", Journal of Co-Operative Organization and Management, Vol. 6 No. 2, pp. 45-52.

Hall, M. and Weiss, L. (1967), "Firm size and profitability", The Review of Economics and Statistics, Vol. 49 No. 3, pp. 319-331.

Hardesty, S.D. and Salgia, V.D. (2004), "Comparative financial performance of agricultural cooperatives and investor-owned firms", Proceeding of the NCR-194 Research on Cooperatives Annual Meeting, Kansas City, MO, USA, 2-3 November, pp. 1-29.

Hart, O. and Moore, J. (1996), "The governance of exchanges: members' cooperatives versus outside ownership", Oxford Review of Economic Policy, Vol. 12 No. 4, pp. 53-69.

Hart, O. and Moore, J. (1998), "Cooperatives vs. outside ownership”, NBER - National Bureau of Economic Research Working Paper No. 6421, pp. 1-55, available at: https://www.nber.org/ system/files/working_papers/w6421/w6421.pdf (accessed 15 March 2021).

Hendrikse, G.W.J. and Veerman, C.P. (2001), "Marketing cooperatives and financial structure: a transaction costs economics analysis", Agricultural Economics, Vol. 26 No. 3, pp. 205-216.

Hernández-Espallardo, M., Arcas-Lario, N. and Marcos-Matás, G. (2013), "Farmers' satisfaction and intention to continue membership in agricultural marketing co-operatives: neoclassical versus transaction cost considerations", European Review of Agricultural Economics, Vol. 40 No. 2, pp. 239-260.

Höhler, J. and Kühl, R. (2014), "Position and performance of farmer cooperatives in the food supply chain of the EU-27", Annals of Public and Cooperative Economics, Vol. 85 No. 4, pp. $579-595$.

Iliopoulos, C. (2003), "Vertical integration, contracts, and the theory of the cooperative organization", Proceedings of the EURESCO Conference on "Vertical Markets and Cooperative Hierarchies: The Role of Cooperatives in the International Agri-Food Industry, Bad Herrenalb, Germany, 12-16 June, pp. 1-22. 
Italian Agricultural Cooperation Observatory (2017), "Rapporto 2017 (report 2017)", pp. 1-174, available at: http://areastudi.legacoop.coop/wp-content/uploads/2017/12/Osservatoriocooperazione_dicembre-2017.pdf (last access 15 March 2021).

Kalogeras, N., Pennings, J.M.E., van der Lans, I.A., Garcia, P. and van Dijk, G. (2009), "Understanding heterogeneous preferences of cooperative members", Agribusiness, Vol. 25 No. 1, pp. 90-111.

Karakas, C. (2019), "Cooperatives: characteristics, activities, status, challenges", EPRS - European Parliamentary Research Service Briefing, pp. 1-12, available at: https://www.europarl.europa.eu/ RegData/etudes/BRIE/2019/635541/EPRS_BRI(2019)635541_EN.pdf (accessed 15 March 2021).

Cooperatives' performance in the wine sector

Lee, J. (2009), "Does size matter in firm performance? Evidence from US public firms", International Journal of the Economics of Business, Vol. 16 No. 2, pp. 189-203.

Lerman, Z. and Parliament, C. (1990), "Comparative performance of cooperatives and investor-owned firms in US food industries", Agribusiness, Vol. 6 No. 6, pp. 527-540.

MacMillan, I.C. and Day, D.L. (1987), "Corporate ventures into industrial markets: dynamics of aggressive entry", Journal of Business Venturing, Vol. 2 No. 1, pp. 29-39.

Markman, G.D. and Gartner, W.B. (2002), "Is extraordinary growth profitable? A study of Inc. 500 high-growth companies", Entrepreneurship Theory and Practice, Vol. 27 No. 1, pp. 65-75.

Nirino, N., Miglietta, N. and Salvi, A. (2020), "The impact of corporate social responsibility on firms' financial performance, evidence from the food and beverage industry", British Food Journal, Vol. 122 No. 1, pp. 1-13.

Notta, O. and Vlachvei, A. (2007), "Performance of cooperatives and investor-owned firms: the case of the Greek dairy industry", in Karantininis, K. and Nilsson, J. (Eds), Vertical Markets and Cooperative Hierarchies: The Role of Cooperatives in the Agri-Food Industry, Springer, Dordrecht, the Netherlands, pp. 275-285.

Porter, P.K. and Scully, G.W. (1987), "Economic efficiency in cooperatives", Journal of Law and Economics, Vol. 30 No. 2, pp. 489-512.

Putterman, L. (1993), "Ownership and the nature of the firm", Journal of Comparative Economics, Vol. 17 No. 2, pp. 243-263.

Rhodes, V.J. (1983), "The large agricultural cooperative as a competitor", American Journal of Agricultural Economics, Vol. 65 No. 5, pp. 1090-1095.

Ross, S.A., Westerfield, R. and Jordan, B.D. (2000), Fundamentals of Corporate Finance, McGraw-Hill, New York, NY, USA.

Royer, J.S. (1991), "A comparative financial ratio analysis of U.S. Farmer cooperatives using nonparametric statistics", Journal of Agricultural Cooperation, Vol. 6, pp. 22-44.

Schlicht, E. and von Weizsäcker, C.C. (1977), "Risk financing in labor-managed economies: the commitment problem”, Zeitschrift Für Die Gesamte Staatswissenschaft, Vol. 133, pp. 53-66.

Sexton, R.J. and Iskow, J. (1993), "What do we know about the economic efficiency of cooperatives: an evaluative survey", Journal of Agricultural Cooperation, Vol. 8, pp. 15-27.

Soboh, R.A.M.E., Lansink, A.O., Giesen, G. and van Dijk, G. (2009), "Performance measurement of the agricultural marketing cooperatives: the gap between theory and practice", Review of Agricultural Economics, Vol. 31 No. 3, pp. 446-469.

Soboh, R., Lansink, A.O. and van Dijk, G. (2011), "Distinguishing dairy cooperatives from investorowned firms in Europe using financial indicators”, Agribusiness, Vol. 27 No. 1, pp. 34-46.

Soboh, R., Lansink, A.O. and van Dijk, G. (2012), "Efficiency of cooperatives and investor owned firms revisited", Journal of Agricultural Economics, Vol. 63 No. 1, pp. 142-157.

Stiglitz, J. (2004), "The role of cooperatives in globalisation”, University of Genua Department of Economic and Financial Sciences Working Paper No. 9/2004, pp. 1-5, available at: http:// www.aciamericas.coop/IMG/pdf/Role-of-Cooperatives-in-Globalisation.pdf (accessed 15 March 2021). 
BFJ 124,13

Stinchcombe, A.L. (2000), "Social structure and organizations", in Baum, J.A.C. and Dobbin, F. (Eds), Economics Meets Sociology in Strategic Management, Emerald, Bingley, Vol. 17, pp. 229-259.

Storchmann, K. (2018), "Introduction to the issue: wine cooperatives", Journal of Wine Economics, Vol. 13 No. 3, pp. 239-242.

Valentinov, V. (2007), "Why are cooperatives important in agriculture? An organizational economics perspective", Journal of Institutional Economics, Vol. 3 No. 1, pp. 55-69.

Vitaliano, P. (1983), "Cooperative enterprise: an alternative conceptual basis for analyzing a complex institution”, American Journal of Agricultural Economics, Vol. 65 No. 5, pp. 1078-1083.

Vrontis, D., Bresciani, S. and Giacosa, E. (2016), "Tradition and innovation in Italian wine family businesses”, British Food Journal, Vol. 118 No. 8, pp. 1883-1897.

Weill, L. (2008), “Leverage and corporate performance: does institutional environment matter?", Small Business Economics, Vol. 30 No. 3, pp. 251-265.

World Cooperative Monitor (2018), "Exploring the cooperative economy", pp. 1-100, available at: https:/monitor.coop/sites/default/files/publication-files/wcm-2018en-1276015391.pdf (accessed 15 March 2021).

Zamagni, S. (2005), “'Per una teoria economico-civile dell'impresa cooperativa” ("For an economic-civil theory of the cooperative enterprise")", in Mazzoli, E. and Zamagni, S. (Eds), Verso una nuova teoria economica della cooperazione (Towards a New Economic Theory of Cooperation), il Mulino, Bologna, Italy, pp. 15-56.

\section{About the authors}

Antonio D'Amato is an Assistant Professor of Corporate Finance at the Department of Economics and Statistics of the University of Salerno, Italy, EU. He holds a PhD in Economics and Management of Public Organizations from the University of Salerno, where he is the Vice-Director of the Postgraduate course in Wine Business. His research mainly focuses on corporate finance and corporate governance.

Giuseppe Festa is an Associate Professor of Management at the Department of Economics and Statistics of the University of Salerno, Italy, EU. He holds a PhD in Economics and Management of Public Organizations from the University of Salerno, where he is the Scientific Director of the Postgraduate course in Wine Business. He is the Chairman of the Euromed Research Interest Committee on Wine Business, and the Scientific Coordinator of the Observatory on Wine Tourism of the Italian Association of the "Wine Cities." His research interests mainly focus on wine business, information systems and healthcare management. Giuseppe Festa is the corresponding author and can be contacted at: gfesta@unisa.it

Amandeep Dhir (DSc, PhD) is a Professor of Research Methods at the University of Agder, Norway. $\mathrm{He}$ is a Visiting Professor at the Norwegian School of Hotel Management, University of Stavanger, Norway. His research appears in the following journals: Technology Forecasting and Social Change, Internet Research, Journal of Retailing and Consumer Services, International Journal of Information Management, Computers in Human Behaviour, Computers in Industry, International Journal of Hospitality Management, Journal of Cleaner Production, Food Quality and preferences, Appetite, Information Technology and People, Australasian Marketing Journal, and Enterprise Information Systems, amongst others.

Matteo Rossi is an Associate Professor of Corporate Finance at the University of Sannio, Benevento, Italy, where he received the $\mathrm{PhD}$ degree in Management, and an Adjunct Professor of Advanced Corporate Finance at LUISS, Rome, Italy. He is the Editor-in-Chief for the International Journal of Managerial and Financial Accounting and for the International Journal of Behavioral Accounting and Finance.

For instructions on how to order reprints of this article, please visit our website:

www.emeraldgrouppublishing.com/licensing/reprints.htm

Or contact us for further details: permissions@emeraldinsight.com 